\title{
The Endeavour to Revise Unequal Treaties in East Asia in the Early 1880s
}

Seunghoon Han*

\section{Introduction}

The term "unequal treaty" is commonly used to describe foreign aggression in Korea, China, and Japan in the nineteenth century. East Asian countries were forced to conclude unequal treaties with Western powers or neighbouring powers without bilateral agreements, equality or reciprocity. The main elements of the unequal treaty were extraterritoriality (consular jurisdiction), low-rate import duties under the loss of tariff autonomy, and most-favoured-nation status. Therefore, it is generally accepted that the unequal treaty system was established in East Asia in the nineteenth century.

The unequal treaty system was conceptualized by John K. Fairbank as a framework that defined the relationship between China and the Western powers since the mid - nineteenth century and was distinct from the Chinese tributary system. ${ }^{1}$ Western powers sought to secure economic interests through the unequal treaty system rather than to secure colonies in East Asia. In this regard, Peter Duus has described the unequal treaty sys-

* Research Professor, German Studies Institute, Korea University, Seoul, South Korea.

1 For sentimental references to the treaty system, see particularly John K. Fairbank, "The Creation of the Treaty System," in The Cambridge History of China, Vol.10. Late Ch'ing, 1800-1911. Part 1 (New York: Cambridge University Press, 1978). 
tem as 'Informal Imperialism.' ${ }^{2}$ In China and Korea, the unequal treaty was one example used to explain why major parts of China were transformed into semi-colonial territories, and why Korea became a Japanese colony. ${ }^{3}$ In Japan, the unequal treaty is also emphasized in order to explain how foreign pressure for commercial and territorial concession was processed. The unequal treaty, by contrast, might become a good source for explaining how Japan triumphed over Western Powers that had not revised their treaties with Japan. In other words, Japan succeeded in the revision of its unequal treaty with Britain just before the first SinoJapanese war (1894), and created the one and only empire in East Asia as a result. ${ }^{4}$ The above-mentioned studies have described Korea, China, and Japan as passive and have emphasized the invasion of Western powers and foreign powers in East Asia since the mid-19th century.

Several recent studies have explored how the unequal treaty was perceived from the point of view of China, Japan, and Korea. First, Dong Wang's research focuses on China's rhetorical use of the unequal treaty through the formation of a national and international discourse in the first half of the 20th century by tracing the process of China's recognition of

2 Peter Duus, Ramon H. Meyers and Mark R. Peattie, eds., The Japanese Informal Empire in China, 1895-1937 (Princeton: Princeton University Press, 1989).

3 Key-Hiuk Kim, The Last Phase of the East Asian World Order: Korea, Japan, and the Chinese Empire, 1860-1882 (Berkeley: University of California Press, 1980); Wang Shaofang, Zhongguo Wai Jiao Shi: Yapian Zhan Zhen Zhi Xin Hai Ge Ming Shi Qi, 1840-1911 (Diplomatic story of China from the Opium War to the 1911 Revolution) (Kaifeng: Henan ren min chu ban she, 1988); Kim Key-Hiuk, "Kaehangŭl Tullŏssan Kukchejŏngch'I (International Politics surrounding the Opening of Portsin Korea)," Han'guksa Simin'gangjwa 7 (August 1990); Lee Byeong Cheon, "Kaehanggwa Pulp'yŏngdŭngjoyakch'ejeŭi Hwangnip (A Study on the Establishment of the Unequal Treaty System during the Port: Opening Period)," Kyŏngjesahak 8 (December 1990).

4 Yamamoto Shigeru, Jōyaku Kaiseishi (History of Treaty Amendment) (Tokyo: Kousan Shouin, 1943); Inō Tentaro, Higashiajia Ni Okeru Fubyōdō Joyaku Taisei To Kindai Nihon (Modern Japan and the Unequal Treaty System in East Asia) (Tokyo: Iwata Shoin, 1995). 
unequal treaties. ${ }^{5}$ Second, Michael Auslin notes Japan's process of negotiating treaties with Western powers from 1858 to 1872, and observes that the revision of unequal treaties led to the birth of modern Japanese diplomacy and a complete change in Japanese society. ${ }^{6}$ Third, Iokibe Kaoru tries to understand not only the negotiations between Japan and the Western powers, but also the relationship between Japan and China, the trends of various powers in Japan, and the recognition of ordinary people, so as to comprehensively understand the process of revising Japan's unequal treaties. ${ }^{7}$ Fourth, some Korean scholars have carried out studies to identify the process of applying extraterritorial rights in Korea and Korea's responses to them. ${ }^{8}$ Most studies show that Japan, China, and the Western powers used extraterritorial rights as one of the ways to expand their power in Korea. However, Han Cheol-ho's research focuses on the Korea government's recognition that extraterritoriality could damage Korean judicial rights in the process of the murder of Queen Myeongseong in 1895 , and gradually attempted to exclude any inequalities in extraterritoriality. $^{9}$

5 Dong Wang, China's Unequal Treaties: Narrating National History (Lanham: Lexington Books, 2008).

6 Michael R. Auslin, Negotiating with Imperialism: The Unequal Treaties and the Culture of Japanese Diplomacy (Cambridge: Harvard University Press, 2009).

7 Iokibe Kaoru, Joyaku Kaiseishi: Hoken Kaifuku eno Tenbo- to Nashonarizumu (Meiji Treaty Revision: Prospect for a Unified jurisdiction and Nationalism) (Tokyo: Yūhikaku, 2010).

8 In Korea, some researches were conducted from 2004 to 2006 under the theme of the Great Powers' Extraterritoriality during the Open-Door Period in Chosun Dynasty. Lee Eun-Ja, Jung Tae-sub, and Han Sung-min studied the subject of China's Exercise of 'Extraterritoriality' and Korea's Response, Han Cheol-ho and Chung Koo-sun, Japan's Exercise of 'Extraterritoriality' and Korea's Response, and Yang Hong-seuk, the U. S. America's Exercise of 'Extraterritoriality' and Korea's Response. In this article, I do not give a list of theses of the above researchers related to extraterritoriality.

9 Han Cheol-ho, “Kabogaehyŏk·Agwanp'ach'ŏn'gi (1894 1897) Ilbonŭi Ch'ioebŏpkwŏn Haengsawa Chosŏnŭi Taeŭng (Japan's Exercise of 'Extraterritorial- 
It is significant that the above-mentioned studies reveal that the perception of the unequal treaty was one of the driving forces for the modern nation-state in China, Japan, and Korea. In addition, it is not clear whether the three countries that attempted to convert to the modern nation-state established mutual relations in the process of recognizing unequal treaties.

In this regard, in the early 1880 s, special attention was paid to the period when the three East Asian countries shared recognition of the unequal treaty. By dispatching officials to Japan in 1880 and 1881, the Korean government intended to revise the commercial portions of the KoreaJapan Treaty of 1876 (Treaty of Kanghwa) that was signed in $1876 .^{10}$ However, the Chinese minister in Japan, He Ruzhang (何如璋), explained to Korean officials that Japan was attempting to revise their own treaties with Western powers to change the inequities of commerce. ${ }^{11} \mathrm{He} \mathrm{Ru}-$ zhang also encouraged China to revise its treaties with the Western powers based on treaties signed by Korea and the Western powers. That is, China, Japan, and Korea were trying to maximize the interests of their countries in the early 1880 s by reducing their economic disadvantages through the revision of their unequal treaties.

Therefore, I will review the cooperation and conflict that took place during the early 1880 s when the three East Asian countries shared their

ity' and Korea's Response, 1894 1897)," Han'gungminjogundongsayŏn'gu 56 (September 2008).

10 See the next articles on Tumojin incident. Kim Kyung-Tae, "Kaehangjikhuŭi Kwansegwŏn Hoebongmunje: 'Pusanhaegwan Susesagŏn'ŭl Chungsimŭro (The Restoration of Tariff-rights in the Late 19th Century: The Case of 'Pusan Tariff Incident')," Han'guksayŏn'gu 8 (September 1972); Park Han-min, “1878nyŏn Tumojin Suserŭl Tullŏssan Choil Yanggugŭi Insikkwa Taeŭng (The recognition and response of the Korea and Japan surrounding the Tumojin Incident in 1878)," Hanilgwan'gyesayŏn'gu 39 (August 2011).

11 Kim Kyung-Tae, "Pulp'yŏngdŭngjoyak Kaejŏnggyosŏbŭi Chŏn'gae: 1880nyŏn Chŏnhuŭi Taeil 'Minjongmunje' (Negotiations for the Amendment of the unequal treaty: 'National problem' against Japan around 1880)," Han'guksayŏn'gu 11 (September 1975). 
perception of the unfair contents of the treaties and carried out their policies. In this article, I will focus on Korea in the early 1880 s, which is a time period previous studies often overlook. Until 1881, Korea had not signed any commercial treaty with a Western power and China, and also sought to revise the Korea-Japan Treaty of 1876 . For that reason, the treaties signed by Korea with Western powers, China, and Japan in 1882 and 1883 will be useful for confirming whether the shared experiences amongst the three countries of being subject to signing unequal treaties was reflected in the treaties signed in the 1880s. Through this research, it is expected that it will be possible to clarify the effect of the process of sharing and internalizing the inequality of the treaties between China, Japan, and Korea in East Asia.

\section{Recognition and Attempts to Revise Unequal Treaties}

\section{Agreement on the Restoration of Tariff Autonomy}

In the mid-nineteenth century, the Western powers, led by Britain, imposed unequal treaties on East Asian countries, beginning with the Nanjing Treaty in 1842. To force the signing of unequal treaties in China and Japan they implemented 'gunboat diplomacy' and the most-favourednation privileges: one of the Western powers, mainly Britain, subdued China and Japan with superior military strength, and imposed unequal treaties on them. Other countries then had equal shares in the advantages of the treaties on the basis of the most-favoured-nation's privileges in China and Japan.

The First and Second Opium Wars, the invasion of Beijing by the Anglo-French alliance, the Japanese expedition by U. S. Admiral Perry's fleet through the Anglo-Satsuma War, and the Shimonoseki War (1864) are examples of Western powers that suppressed China and Japan by force. China and Japan, surrendering to the Western powers, had to sign unequal treaties - the Treaty of Tientsin (1858), Convention of Peking 
(1860), Kanagawa Treaty (1854), Ansei five-power Treaties (1858), and the Tariff Convention (1866). As a result, Western powers were equally guaranteed a low import tariff of $5 \%$ on conventional duties, including the opening of ports, and privileges of extraterritoriality in China and Japan.

It was neighbouring Japan that imposed an unequal treaty on Korea on behalf of Western powers. Although Japan failed to get its most favoured nation privileges due to Korea's opposition, Japan applied extraterritoriality, the opening of ports, and the loss of Korea's tariff in the Korea-Japan Treaty of 1876. Whereas tariffs of 5\% were applied in China and Japan, Japan imposed a tax-free clause in Korea.

Immediately after the conclusion of the treaty, Korea suffered negative effects due to a loss of tariff autonomy and tax-free imports and exports. The outflow of rice from to Japan led to a rise in rice prices and food shortages in Korea. Due to the increase in imports from Japan, silver moved from Korea to Japan in large quantities. In the end, the Korean government installed customs in Tumojin (near Pusan) in 1878, and imposed tariffs on import and export items. Then the Japanese government and merchants vigorously opposed the imposition of tariffs by claiming that Korea violated the treaty, and Korea was forced to shut down its customs. ${ }^{12}$ Instead, Korea sent Kim Hong-jip to Japan in 1880 to revise the 1876 Korea-Japan Treaty.

The Ministry of Foreign Affairs of Japan refused to negotiate with Kim Hong-jip. The reason for the refusal was that Kim Hong-jip was not entrusted with full authority from the Korean government. The Japanese Ministry of Foreign Affairs abused the situation since the Koreans lacked an understanding of the modern treaty, and used this as the reason for refusal in negotiation. ${ }^{13}$ In the end, Kim Hong-jip could not achieve the revision of the Korea-Japan Treaty of 1876.

12 Kim Kyung-Tae, "Kaehangiikhuŭi Kwansegwŏn Hoebongmunje," 693-723; Park Han-min, "1878nyŏn Tumojin Suserŭl Tullŏssan Choil Yanggugŭi Insikkwa Taeŭng," 379-96.

13 Kim Kyung-Tae, “Pulp'yŏngdŭngjoyak Kaejŏnggyosŏbŭi Chŏn'gae,” 172-6. 
However, the Koreans were also advised that their economic situation took a sharp turn for the worse due to unequal treaties. When Kim Hongjip had an interview with He Ruzhang (何如璋), the minister of China in Japan, on July 1880 in Tokyo, observed that:

“As a general rule, Western powers levy an average 30\% tariff rate on imports. In addition, they can impose protective duties on goods which they don't want to import, so they can raise tariff walls against foreign goods ...... In brief, if one state had one's Tariff Autonomy, trading profit could be made a monopoly of not by a trade partner but by one's country. Therefore, although one's country trades with all countries, there would be trading profit without losses ..... East Asian states have been suffering a lot of losses because nobody had known this type of standardization before the opening ports. Japan has recently discovered it, so it is trying to revise their treaties with Western Powers. In my view, your state can get a jump on Japan if your country takes the opportunity by the horns."14

He explained that China and Japan suffered many losses because Western powers excluded tariff autonomy. In addition, he stressed that Korea should follow his advice that Korea needed to conclude more equal treaties with Western powers than China and Japan had by following Japan's attempt to revise their treaty. ${ }^{15}$

When Kim Hong-jip returned to Korea, he reported to King Kojong the unequal effects of China and Japan's treaties with Western powers. As the next step of Kim Hongjip's mission, the Korean government determined that Lee Hŏnyŏng and Min Chŏngmuk, as part of the Korean Courtiers Observation Mission (朝士視察團), secretly would be sent to Japan to

14 “大淸欽使筆談,” in Kaebangkwa Yesok, ed. Song Byeong-Ki (Seoul: Tan'guk Taehakkyo, 2000), 26.

15 Kim Kyung-Tae, “Pulp'yŏngdŭngjoyak Kaejŏnggyosŏbŭi Chŏn'gae,” 176-7. 
research its policy on customs duties on February 1881. They inspected the customs office in Yokohama, the Ministry of Finance, and Foreign Affairs Japanese officials provided Korean missions not only with information about the customs system but also with copies of treaties between Japan and Western powers. In addition, they heard about unequal treaties from Japanese officials. After their mission, they reported to King Kojong on the tariff policy. ${ }^{16}$

They explained that China and Japan suffered from an economic crisis because of a trade deficit in terms of the growing trade imbalance due to low tariff rates on imports. Consequently, they recommended that Korea should impose $5 \%, 10 \%, 20 \%$, or $30 \%$ tariff rates which were dissimilar to the low 5\% tariff rate in China and Japan. Their reports signified that Korea not only needed to revise the treaty with Japan but also should conclude treaties with Western powers that included tariff autonomy.

\section{The Draft Treaty}

The Korean government tried to avoid inequality in the treaties that China and Japan received from Western powers, especially in terms of tariffs. The departure was the preparation of a draft treaty with Japan to revise the 1876 Korea-Japan Treaty. Korea made a draft treaty (新修通商 章程草案) based on the above mentioned findings and the Japanese draft treaty in $1880 .^{17}$

As seen in Table 1, in the Korean revision, the tariff rate for major imports was set at $10 \%$, and the tariff rate for the rest of imports was 5 $35 \%$. Above all, Korean officials hoped to protect their tariff autonomy

16 Han Seunghoon, “Choyŏngjoyak (1883.11) kwa Pulp'yŏngdŭngjoyakch'ejeŭi Chaejŏngnip (The Treaty Concluded between Korea and Britain in 1883 and the Reconstruction of the Unequal Treaty System)," Han'guksayŏn'gu 135 (December 2006): 225-6.

17 Han Seunghoon, “Choyŏngjoyak (1883.11) kwa Pulp'yŏngdŭngjoyakch'ejeŭi Chaejŏngnip," 226-7. 
Table 1. Korean draft treaty in 1881 , Japanese draft treaty in 1880 , and China or Japan treaties with Western powers.

\begin{tabular}{|c|c|c|c|}
\hline & 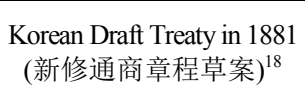 & $\begin{array}{l}\text { Japanese Draft } \\
\text { Treaty in } 1880^{19}\end{array}$ & $\begin{array}{l}\text { China or Japan } \\
\text { Treaties with West- } \\
\text { ern powers }\end{array}$ \\
\hline \multirow{6}{*}{$\begin{array}{l}\text { Tariff Rate on } \\
\text { Imports }\end{array}$} & ship's stores: $5 \%$ & $\begin{array}{l}\text { medicine, minerals, } \\
\text { corn: } 5 \%\end{array}$ & \multirow{6}{*}{$5 \%$} \\
\hline & articles of daily use: $10 \%$ & $\begin{array}{l}\text { metal, clothing and so } \\
\text { on: } 10 \%\end{array}$ & \\
\hline & \multirow{2}{*}{ Luxury goods: $25 \%$} & $\begin{array}{l}\text { natural oil, paper, and } \\
\text { so on: } 15 \%\end{array}$ & \\
\hline & & $\begin{array}{l}\text { a domestic, oil, and so } \\
\text { on: } 20 \%\end{array}$ & \\
\hline & \multirow[b]{2}{*}{ oil: $35 \%$} & $\begin{array}{l}\text { luxuries, and so on: } \\
25 \%\end{array}$ & \\
\hline & & $\begin{array}{l}\text { tobacco, alcoholic } \\
\text { beverages and so on: } \\
30 \%\end{array}$ & \\
\hline $\begin{array}{l}\text { Tariff Rate on } \\
\text { Exports }\end{array}$ & $5 \%$ & $5 \%$ & $5 \%$ \\
\hline $\begin{array}{l}\text { Tariff } \\
\text { Autonomy }\end{array}$ & yes & yes & no \\
\hline
\end{tabular}

through the draft. ${ }^{20}$ The Korean draft was similar to Japan's draft; the import tariff rate, which was divided into 6 levels from 5\% to $30 \%$ and the restoration of tariff autonomy. This was the result of not only Korea's acceptance of parts of Japan's draft and but also Korea's willingness not to repeat the economic mistakes of China and Japan due to the single import tariff rate of $5 \%$.

Meanwhile, Yi Dong-in, the member of the Kaewha-tang (the Progressive Party) drafted the treaty, while taking into consideration the signing

18 Nihon Gaiko Monjo (Documents on Japanese Foreign Policy), ed. Gaimushō, vol. 14 (Tokyo: Nihonkokusairengōkyōkai, 1951), 315-20.

19 Joyakukaiseikankei Nihongaikobunsho (Documents on Japanese Foreign Policy: Treaty Amendments), ed. Nihon Gakujutsu Shinkōkai, vol. 1 (Tokyo: Nihon Kokusai Rengō Kyōkai, 1951), 12-49.

20 Lee Byeong Cheon, “Kaehanggwa Pulp'yŏngdŭngjoyakch'ejeŭi Hwangnip,” 69. 
of treaties with Western powers. He stipulated that a $10 \%$ flat rate should be imposed on major imports, thereby maintaining a higher tax rate than the $5 \%$ import duty rate of both the China and Japan. He also expressed his willingness not to reflect the lower rate of import tariffs applied in China and Japan to the treaties that Korea would conclude with the Western powers. ${ }^{21}$

In comparison with Japan and Korea, China was unable to revise its unequal treaties with those countries which had forced her to conclude unequal treaties. China, however, explored ways to revise unequal treaties by using its influence in the process of treaty negotiation between Korea and the United States. Actually, instead of Korean officials, Li Hongzhang (李鴻章), a Viceroy in China, wrote most of the provisions of the Korean - American Treaty, and led the negotiations with Shufeldt, the Commodore of the United States in Asia. During negotiations, Huang Tsun-hsien (黃遵憲) wrote a draft, including 10\% and 30\% tariff rates, and sent it to Li Hongzhang. ${ }^{22}$ He Ruzhang, also, sent a proposal for the Korean - American Treaty. He observed that through the Korean - American Treaty, China could revise its own unequal treaties with Western powers on the basis of the Korean - American Treaty. ${ }^{23}$ China attempted to create the possibility of revision of its unequal treaties by means of the Korean - American Treaty.

21 "The Agent also sketched out a draft Treaty of Commerce and Friendship, framed in a liberal spirit, with a fixed Tariff at 10 per cent. upon the chief articles only of import," Kennedy to Granville, Tokio, November 21, 1880 (Received January 3, 1881), No.179, FO 46/258. (FO: Records created or inherited by the Foreign Office in the UK).

22 Song Byeong-Ki, "Kimyunsik, Leehongjangŭi Pojŏng.Ch'ŏnjinhoedam (Sang): Chomijoyak Ch'egyŏl (1882) ŭl Wihan Choch'ŏnggyosŏp (Kim Yun-Sik - Li Hung-chang Talks at Poating and Tientsin: The Korean-Chinese Negotiations for the Conclusion of Korean-American Treaty in 1882)," Tongbanghakchi 44 (November 1984): 184-5.

23 Song Byeong-Ki, "Kimyunsik, Leehongjangŭi Pojŏng·Ch'ŏnjinhoedam (Sang)," 197-8. 
To achieve this, China exercised its influence over the conclusion of the treaty between Korea and two Western powers, Britain and Germany, immediately after the Korean - American Treaty. Especially, China also suggested that Britain and Germany conclude the same treaty as the United States had done. The reason was that China sought to revise their unequal treaties with the United States, Britain, and Germany on the basis of the same treaties which had been signed with Korea in 1882 .

As seen in Table 2, the treaties that Korea concluded with the United States, Britain, and Germany stipulated tariff rates at $10 \%$ and $30 \%$, and guaranteed Korea's tariff autonomy. Although these treaties were the result of China's mediation, it was also a reflection of Korea's intention not to conclude unequal treaties in the early 1880 s. Moreover, in 1882, when Korea signed treaties with the Western powers, Japan proposed a draft for revising its treaties with Western powers. In the draft, Japan fixed the tariff rate on major imports at $10 \%$, applied the other tariff rate of $5 \sim$ $25 \%$, and ensured its tariff autonomy.

Table 2. Korean treaties with Western powers and the Japanese draft treaty with Western powers in 1882.

\begin{tabular}{|c|c|c|}
\hline & $\begin{array}{l}\text { Treaties between Korea and Western powers } \\
\text { (the United States, Britain, and Germany) in } 1882\end{array}$ & $\begin{array}{l}\text { Japanese Draft } \\
\text { Treaty in } 1882^{24}\end{array}$ \\
\hline \multirow{5}{*}{$\begin{array}{l}\text { Tariff Rate on } \\
\text { Imports }\end{array}$} & \multirow{2}{*}{$\begin{array}{l}\text { articles of daily use: not to exceed an ad valorem } \\
\text { duty of } 10 \%\end{array}$} & $5 \%$ \\
\hline & & $10 \%$ \\
\hline & \multirow{3}{*}{$\begin{array}{l}\text { luxury items: not to exceed an ad valorem duty of } \\
30 \%\end{array}$} & $15 \%$ \\
\hline & & $20 \%$ \\
\hline & & $25 \%$ \\
\hline $\begin{array}{l}\text { Tariff Rate on } \\
\text { Exports }\end{array}$ & $5 \%$ & $5 \%$ \\
\hline $\begin{array}{l}\text { Tariff } \\
\text { Autonomy }\end{array}$ & yes & yes \\
\hline
\end{tabular}

24 Joyakukaiseikankei Nihongaikobunsho Bessatsu Joyakukaiseikeikagaiyo- (Documents on Japanese Foreign Policy Supplement: Chronology of Treaty Amendments) (Tokyo: Nihon Kokusai Rengō Kyōkai, 1950), 189-200. 
However, the Treaties of Korea with the United States, Britain and Germany guaranteed extraterritorial rights to these countries. Considering that Japan had already insisted on the abolition of extraterritoriality before the 1880 s, it could not be regarded as a failure for China or Korea to recognize Japan's efforts to abolish extraterritoriality. In this regard, the answer can be partially found in Chao-hsients'e-lüeh (朝鮮策略, The True Policy for Korea).

"At the same time, the customs and laws of Europe and Asia being dissimilar, it is not possible to place foreign traders under the jurisdiction of the local authorities. It should be distinctly understood that they are under the jurisdiction of the Consul, but that, at a fitting moment, Korea may propose to alter the arrangement. A limit should be established to the authority of the Consuls, and if the foreign residents are thus deprived of their talisman, they will not be able to make trouble." 25

Huang Tsun-hsien, author of The True Policy for Korea, pointed out that it was difficult to control Westerners residing in Korea with the Korean legal system because the Western lifestyle and laws were very different. In this regard, he suggested Korea should leave its legal management of Westerners in the hands of the consular offices in the trade ports. Considering that Huang Tsun-hsien was the secretary of the Chinese Legation in Japan, it can be inferred that China had recognized extraterritorial rights from a reciprocal viewpoint as reflected in The True Policy for Korea.

Nevertheless, Huang Tsun-hsien could not completely dismiss Japan's alleged abolition of the right to extraterritoriality, so he wrote that when the time was right, Korea should abolish extraterritorial rights. Although a

25 Song Byeong-Ki, ed., Kaebangkwa Yesok (Seoul: Tan'guk Taehakkyo, 2000), 62; "The True Policy for Corea: a Private Memorandum by Huang Tsun-hsien, Secretary of the Chinese Legation in Japan," Inclosure in No.47, FO 881/4595. 
rigorous analysis is required, the treaties signed by Korea with Western powers in 1882 reflected a clause that Korea could eliminate extraterritoriality when its legal system was identical to that of these countries. When Korea and Britain signed a new treaty (the second Korea-Britain Treaty) in 1883, Korea insisted that a conditional abolition clause should be inserted. ${ }^{26}$ In other words, Korea's revision, which reflected China's recommendation, can be regarded as taking a step toward gradually eliminating extraterritorial rights.

In conclusion, in the early 1880 s, it was very possible to revise the unequal treaty system in East Asia. At the core of the revision was the restoration of tariff autonomy and an increase in import duties in the three East Asian countries. In particular, Korea's treaties with the United States, Britain and Germany in 1882 guaranteed Korea's tariff autonomy and the import tariff rate was higher than the $5 \%$ that was implemented in China and Japan by Western powers. China had plans to ask the Western powers to revise their treaties based on these new treaties, and the customs provisions of the draft that Japan submitted to the Western powers in 1882 were similar to the contents of these treaties. Although Korea guaranteed extraterritorial rights to Western powers in these treaties, they had the potential to bring about a change in the unequal treaty system that had been introduced to East Asia, beginning with the Nanjing Treaty.

\section{The Failure to Revise the Unequal Treaties}

The Conflict between China and Japan in Korea

The attempt to revise the East Asian unequal treaty system triggered by the treaties signed by Korea with the Western powers was unsuccessful. Above all, Britain, which opposed the changes in the treaty system, re-

26 Han Seunghoon, "Choyŏngjoyak (1883.11) kwa Pulp'yŏngdŭngjoyakch'ejeŭi Chaejŏngnip," 244. 
fused to ratify the treaty signed with Korea in 1882 with Germany and signed a new treaty (the second Korea-Britain Treaty) in November 1883. ${ }^{27}$ The second Korea-Britain Treaty was intensively reflected in the treaties applied in East Asia in favor of Western powers. In addition, the United States, which had originally ratified the American - Korean Treaty, used its most-favored-nation privileges to have an equal share in these treaties.

However, the failure to reform the unequal treaty system was not only due to the role of Britain. Competition and conflict between China and Japan to secure influence in Korea also played an important role.

Shortly after the Imo rebellion, China perceived that her "vassal state" Korea was exposed to the menace of Japan through the Imo rebellion in spite of the treaties between Korea and Western powers. ${ }^{28}$ After all, Li Hongzhang forced Korea to accept the Regulations for Maritime and Overland Trade between Chinese and Korean Subjects (朝清商民水陸貿易 障程), which stipulated that Korea was a tributary state of China on October 1882. Moreover, Korean - Chinese Commercial Regulations put Korea on unequal footing with China economically by means of disproportionate provisions: permission to trade between the open ports in Korea, the right to exercise Chinese extraterritoriality and consular jurisdiction, the right to go into the interior to trade, and only a $5 \%$ tariff rate on all

27 Research into the process of the second Korea-Britain Treaty is discussed below. Kim Hyun-soo, Taeyŏngjegugŭi Tongasia Oegyojuyŏk: Haeri S. P'ak'ǔsŭ (Harry S. Parkes: Leader of Great Britain's diplomacy in East Asia) (Yongin: Dankook University Press, 2011); "P'ak'ŭsŭ (Sir Harry Parkes) Kwallyŏn Saryodŭrŭl T'onghae Pon 'Hanyŏngsuhot'ongsangjoyak' Ch'egyŏl Kwajŏng (A Study of the AngloKorean Treaty by Reviewing Sir H. Parkes` Documents)," Yŏnggugyŏn'gu 11 (June 2004); Han Seunghoon, "Choyŏngjoyak (1883. 11) kwa Pulp'yŏngdŭngjoyakch'ejeŭi Chaejŏngnip."

28 The Imo rebellion was an uprising caused by an old-fashioned army and antiforeign party centred on King Kojong's father, so called Heungsŏn Taewŏngun, that were alienated from the Korean government's progressive reform policy in July 1882. 
imports.

On arguing that the Regulation was a privilege of the suzerain state, China was willing to prevent Western powers and Japan from having an equal share in the Korean - Chinese Commercial Regulations by virtue of a most-favored-nation provision. It, however, was true that there was a contradiction between the Regulation and the Korea-Western powers treaties; on the contrary, the Regulation was similar to the treaties between China or Japan and Western powers. That was why Britain demanded that the Regulation should include equal shares. Consequently, China caused difficulty in the revision process of the unequal treaties for itself.

Even if Japan was unable to destroy Chinese influence in Korea after the Imo rebellion, Japan endeavoured to gain the same privileges as China. Japan and Korea had been in negotiations over the revision of their treaty since 1880 . Japan was originally positive about approving a Korean proposal similar to the Korean-American Treaty, ${ }^{29}$ however, its attitude about the revision changed and aligned with Britain's policy after the announcement of the Korean - Chinese Commercial Regulations. Concerned about losing an economic competitive edge with China in Korea due to the Korean - Chinese Commercial Regulations, Japan also required that the Korean - Chinese Commercial Regulations include three equal shares. $^{30}$

Inoue Kaoru (井上馨), the minister of Foreign Affairs in Japan, not only let Harry. S. Parkes know of Japan's desire to participate in British

29 "It was difficult for Corea to preserve her integrity unless she received either the material or moral support of some more powerful state and it was natural that material support should be extended by a neighbouring Power." Francis C. Jones, "Foreign Diplomacy in Korea 1866 1894" (PhD diss., Harvard University, 1935), 345.

30 "He (Inoue Kaoru) clearly intimated to them (Korean Envoys) that Japan could not agree to a higher Customs Tariff than that which Corea had lately accorded to China, and which was settled on a basis of 5 per cent." Parkes to Granville, Tôkiô, January 12, 1883. No.3 (Confidential). FO 405/33. 
policy on the first Korea-Britain Treaty, ${ }^{31}$ but also tried to intimidate Kim Okkyun, a Korean envoy, into approving the British proposal of an equal allotment in the Korean - Chinese Commercial Regulations. ${ }^{32}$ The Japanese attitude towards Britain and Korea was caused by keen competition with China in Korea; however, there was a contradiction between Japanese treaty policies toward Western powers, and toward Korea. Thus, Parkes observed that there was no necessity for concentrating on the first Korea-Britain Treaty in connection with the revision of the foreign treaties with Japan. ${ }^{33}$

With the tensions between China and Japan intensifying, they competed to gain special economic privileges in Korea. On the other hand, Korea endeavoured to reduce the privileges enjoyed by China and Japan in Korea to a level of those granted to the United States and Britain, ${ }^{34}$ because Korea had already known that unequal treaties had a bad influence on the domestic economy looking at the cases of China and Japan. When William. G. Aston, a British consul in Kobe, demanded an equal share of the

31 "It denoted, he observed, that China intended to assume great powers of control over Corea, and to secure exclusive commercial privileges in that country. He believed this action to be chiefly directed against Japan, although it also materially affected the interests of those nations who were about to enter into Treaty relations with Corea. He was anxious to know what course would be taken by the Powers who had made Treaties with Corea, and he desired that the action of the Japanese Government should be influenced by and should conform, if circumstances so permitted, with their proceedings." Parkes to Granville, Tôkiô, December 21, 1882, No.172 (Confidential), FO 405/33.

32 "Corea could not expect Western Powers, any more that Japan, to accept a Tariff of 10 to 30 per cent. on their imports when those of China were to be admitted at 5 per cent., as it would be impossible for other foreigners to compete with Chinese under such conditions." Parkes to Granville, Tôkiô, January 12, 1883. No.3 (Confidential), FO 405/33.

33 Parkes to Granville, Tôkiô, May 14, 1883. No.106 (Confidential), FO 405/33.

34 Parkes to Granville, Tôkiô, April 21, 1883. No.59 (Confidential), FO 405/33; Han Seunghoon, "Choyŏngjoyak (1883. 11) kwa Pulp'yŏngdŭngjoyakch'ejeŭi Chaejŏngnip," 223-7. 
Korean - Chinese Regulations during his two visits to Korea, ${ }^{35}$ Korean officials observed that China was prepared to relinquish their right of trade in the interior and at the capital, and their promised monopoly of the interport or coastal trade, and would also agree to a similar tariff on their maritime trade as that of the European treaties with Korea. ${ }^{36}$ In addition, the Korean authority also argued that Japan would not oppose a $10 \%$ tariff rate if the other Powers consented to its adoption. ${ }^{37}$

In other words, Korea was not merely aware of what unequal treaties were but also tried to avoid them as well. What is more, Korea's struggle for the "Exclusion of Inequality" seemed to be a possible realization in compliance with the ratification of the Korea-United States Treaty which was identical with the first Korea-Britain Treaty. However, Japan still rejected the Korean draft as 'unequal' in comparison with the Korean Chinese Commercial Regulations, and finally concluded the Regulations under which Japanese trade was to be conducted in Korea (朝日通商章程) on July 25,1883 . Although an average tariff rate on imports was $8 \%$, Japan stipulated that only a $5 \%$ tariff rate should be levied on all Japanese goods, and Korea should give Japan the right to have an equal share of all the treaties without conditions through their most-favored-nation status.

In addition, Li Hongzhang proposed that China could help to revise the first Korea-Britain Treaty since Britain hoped to conclude a treaty with the "Chinese vassal state" of Vietnam, which was confronted with the threat of a French military invasion on May 30, $1883 .{ }^{38}$ For the purpose of defending Vietnam from France, China was willing to acquiesce to the revision of the first Korea-Britain Treaty, one of the treaties signed between Korea and the Western powers that China had mediated with a

35 Aston to Parkes, April 11, 1883. Inclosure 2 in No.64 (Confidential), FO 405/33.

36 Parkes to Granville, Tôkiô, June 10, 1883. No.98 (Confidential), FO 405/33.

37 Aston to Parkes, Tôkiô, April 11, 1883. Inclosure 2 in No.64 (Confidential), FO $405 / 33$.

38 Hughes to Granville, Shanghae, May 30, 1883, No.131 (Confidential), FO 405/33; Han Seunghoon, “Choyŏngjoyak (1883. 11) kwa Pulp'yŏngdŭngjoyakch'ejeŭi Chaejŏngnip,” 239. 
view to the revision of its own treaties with the Western powers.

The Treaties of Korea signed with the Western powers in 1882 could be the basis for the revision of treaties concluded between China or Japan and the Western powers. Actually, China planned to insist on the revision of the treaties with the Western powers based on the Korean treaties. However, while Britain and Germany refused to ratify the treaty with Korea, China forced Korea to accept the Korean - Chinese Commercial Regulations, which contained the same kind of unequal content in the treaties in effect in China and Japan. This gave Britain a reason to reject the treaty with Korea (1882) and the request for a revision of the treaty based on the Korean - Chinese Commercial Regulations.

Meanwhile, Japan asked Britain, the United States and Germany to ratify the treaty with Korea as a way to disable China's policy of strengthening its suzerain position with Korea. However, Japan had a negative perception of the content related to trade in the Korean treaties with the Western powers. Especially when the Korean - Chinese Commercial Regulations was announced, Japan expected that its merchants would be at odds with Chinese merchants in Korea. Thus, Japan insisted on an amendment of Korea's treaties with the Western countries on the basis of the Korean - Chinese Commercial Regulations. In the end, Japan revoked the draft of the treaty which it had proposed to the Western powers and acted in a contradictory way by setting a tariff rate of $8 \%$ according to conventional tariffs in the Korea - Japan Commercial Regulations.

\section{The Truth behind the $7.5 \%$ Rate}

Korea concluded new treaties with Britain and Germany on November 26,1883 . In these treaties, the tariff rate for major imports was set at $7.5 \%$, and the tariff rate for other imports was set at $5 \sim 20 \%$. As shown in the table, it seems that the tariff rates on imports were higher than the tariff rates in force in China and Japan. The Korean government, which had originally intended to pursue customs tariffs based on the previous agreement, was disappointed that the tariff rate on major imports de- 
creased from $8 \%$ to $7.5 \%$.

However, the Korean government did not perceive a tariff reduction as an unequal measure. Queen Myŏngsŏng, who was behind the signing of the treaty at the time, said that although there were many items with an import tariff of $7.5 \%$, the import duty rate items, which applied a tax rate of $8 \%$ according to the Korea - Japan Commercial Regulations, were set at $10 \%$, and such an action could actually benefit the country and not harm it. ${ }^{39}$ Actually, the tariff rate of 57 products among the 200 items listed in the British draft was raised and reflected in the bylaws of the second Korea-Britain Treaty. ${ }^{40}$

The reason why Queen Myŏngsŏng supported the import tariff rate of $7.5 \%$ was also due to the relationship between Korea and China. At the time, China was strengthening its intervention in Korea under the pretext of its suzerain-vassal relationship. King Kojong and Queen Myŏngsŏng attempted to offset China's interference by concluding a treaty with Britain, which proceeded without Chinese mediation. Queen Myŏngsŏng believed that "if the British and German ambassador plenipotentiaries went back without signing the treaty, the Chinese would laugh out loud clapping their hands at the sight, and the Chinese would be even more proud over us." ${ }^{41}$ From that standpoint, she stood on the brink of accepting the British demand for $7.5 \%$ import duties. In other words, the Korean government accepted the lower import tariff rate of $7.5 \%$ because of its political potential of curtailing China's policy of strengthening its suzerain relation with Korea.

Lucius H. Foote, the U. S. minister to Korea and an unofficial consultant to King Kojong at the time of the signing of the second Korea-Britain

39 Yunch'ihoilgi (Diary of Yun Ch'i-ho), September 7, 1883.

40 Han Seunghoon, “19Segi Huban Chosŏnŭi Taeyŏngjŏngch'aek Yŏn'gu (1874 1895): Chosŏnŭi Kyunsejŏngch'aekkwa Yŏnggugŭi Kansŏpchŏngch'aegŭi Kwan'gye Chŏngnipkwa Kyunyŏl (Korean Policy toward Britain in the late 19th century: The Establishment and Rupture between Korean Policy of Balance of Power and British Policy of Intervention)" (PhD diss., Korea University, 2015), 98.

41 Yunch'ihoilgi, September 7, 1883. 
Treaty, also assessed the import duties at $7.5 \%$. He preferred to adhere to the $8 \%$ import duty rate, but on the other hand advised that Korea allow a $7.5 \%$ rate if it would not impair Korean interests. ${ }^{42}$ Furthermore, when Britain decided to set the import tariff rate on Western cotton at 7.5\%, Foote said to Min Yŏngmok, the minister of Foreign Affairs in Korea, "I did not think that Britain would allow a $7.5 \%$ rate of Western cotton. If it does, it is a thing to be honoured for Korea." ${ }^{43}$ Perhaps he predicted that Britain would import cotton, a major export item, at a 5\% rate in China and Japan. Regardless, his remark played an important role in establishing the $7.5 \%$ import tariff rate as the 'proper tariff rate' without economic damage to Korea.

As seen in Table 3, although Korea did not achieve the import tariff rate of $10 \%$, it was $2.5 \%$ higher than the $5 \%$ that was implemented in China and Japan. Moreover, Korea applied import tariffs on other items at a rate of $5 \%, 10 \%$, or $20 \%$ in the second Korea-Britain Treaty. This was different from China and Japan, which applied only a single tax rate of $5 \%$. Korea seemed satisfied with the import tariff rate of $7.5 \%$ proposed by Britain, as it seemed to have been more favorable to Korea than China and Japan. Why did the U.K. apply a $7.5 \%$ rate to the second KoreaBritain Treaty? The answer can be found in the conversation between $\mathrm{Li}$ Hongzhang and Parkes.

Soon after the second Korea-Britain Treaty was signed, Parkes met Li Hongzhang in Tianjin. On the spot, Parkes said that the average import tariff rate should not exceed $7.5 \%$ for China's consideration. In response, Li laughed aloud and said $7.5 \%$ was the amount of the import duties and transit duties of China combined. ${ }^{44}$ In other words, Li Hongzhang said China's actual import duties were $7.5 \%$, not $5 \%$. So, F. B. Johnson, the Chairman of the Hong Kong General Chamber of Commerce had criti-

42 Yunch'ihoilgi, September 7, 1883.

43 Yunch'ihoilgi, September 9, 1883; Han Seunghoon, “Choyŏngjoyak (1883.11) kwa Pulp'yŏngdŭngjoyakch'ejeŭi Chaejŏngnip," 242.

44 Parkes to Granville, Tien-tsin, December 7, 1883, No.13, FO 405/34. 
Table 3. China and Japan treaties with Western powers, and the Second Korean Anglo Treaty of 1883 .

\begin{tabular}{|c|c|c|c|}
\hline & & $\begin{array}{l}\text { China or Japan with } \\
\text { Western powers }\end{array}$ & $\begin{array}{c}\text { The Second Korean -Anglo } \\
\text { Treaty in } 1883\end{array}$ \\
\hline \multirow{6}{*}{ Tariff Rate } & \multirow{4}{*}{ Imports } & \multirow{4}{*}{$5 \%$} & $5 \%$ \\
\hline & & & $7.5 \%$ \\
\hline & & & $10 \%$ \\
\hline & & & $20 \%$ \\
\hline & Exports & $5 \%$ & $5 \%$ \\
\hline & Tariff Autonomy & No & No \\
\hline \multirow{2}{*}{\multicolumn{2}{|c|}{ Interior trade }} & China: Admission & \multirow{2}{*}{ Admission } \\
\hline & & Japan: Prohibition & \\
\hline \multicolumn{2}{|c|}{ Trade between the Open Ports } & Admission & Admission \\
\hline
\end{tabular}

cized the first Korean-American treaty as having a high import duty rate and suggested that the import duty rate to be applied in Korea be $7.5 \%$, which was actually practiced in China. ${ }^{45}$ Parks accepted and reflected this in his proposal of the draft treaty, ${ }^{46}$ and pushed it in Korea. In other words, the $7.5 \%$ import tariff rate imposed by Parkes was merely adopting the actual tariff rate in force in China.

So, what was the situation in Japan? As shown in the Table, Although Japan applied 5\% import duties, all foreign merchants did not have freedom to trade in the interior of Japan. In Japan, foreign merchants were able to carry out limited commercial activities only at open ports. On the other hand, they were allowed the freedom to trade in the interior of China. Korea should also secure the freedom of interior trade to British subjects, and there was no additional tax on imports on import duties that had already been levied in Korea. In regard to customs tariffs, Parkes observed that:

45 Hong Kong General Chamber of Commerce (written by Chairman: F. B. Johnson) to Granville, Hong Kong, January 20, 1883. Inclosure 2 in No.48, FO 405/33.

46 Parkes to Granville, Tôkiô, June 22, 1883. No.133. FO 405/33; Han Seunghoon, “Choyŏngjoyak (1883. 11) kwa Pulp'yŏngdŭngjoyakch'ejeŭi Chaejŏngnip,” 234. 
"Cotton and woollen manufactures and dyes, which will probably form six-tenths of the foreign trade with Korea, will pay a 7.5 per cent rate of duty, cotton yarns, metals, sugar, drugs, medicines, and kerosene, which may comprise three-tenths of that trade, will pay 5 per cent, and the remaining tenth of the trade will certainly not pay more than a 10 per cent rate. The result, therefore, is an average rate of 7 per cent." $" 47$

As a result, the customs tariff on imports in Korea was never higher than in China and Japan. However, Korea thought that it could avoid the unequal import tariff rates suffered by China and Japan through a simple comparison of $5 \%$ and $7.5 \%$, but in fact the actual rates were applied almost identically as in China and Japan. As a result, the attempt to revise the unequal treaties, which was centerd on tariffs raised in East Asia in the early 1880 s, was actually a failure.

\section{Conclusion}

In summary, China, Japan, and Korea shared the view that the treaties implemented by the Western powers were unequal for these countries in the early 1880 s. China, Japan and Korea showed deep sympathy over the negative effects of the low tariff rate on the national economy due to the loss of tariff autonomy. These countries cooperated in revising the unequal content of treaties through amendments to various treaties. The treaties that Korea signed with the United States, Britain, and Germany in 1882 were also a result of this.

However, attempts by China, Japan, and Korea to revise unequal treaties were unsuccessful. The superficial reason was that Britain, who effec-

47 Parkes to Granville, Tien-tsin, December 6, 1883, No.12, FO 405/34; Han Seunghoon, “Choyŏngjoyak (1883. 11) kwa Pulp'yŏngdŭngjoyakch'ejeŭi Chaejŏngnip," 243-4. 
tuated the treaty system in East Asia, concluded the 1883 treaty with Korea without ratifying the treaty with Korea in 1882 . Behind the scenes, however, there were conflicts between China and Japan to expand their political and economic influence in Korea. The classic examples of this were the Korean - Chinese Commercial Regulations (1882) and the Korean - Japanese Trade Regulation (1883). Korea was also satisfied with a $7.5 \%$ tariff rate higher than the $5 \%$ tariff implemented in China and Japan, and was politically determined to thwart China's policy on the strengthening its suzerain status in Korea.

Nevertheless, conflict between China and Japan was inevitable. In the latter half of the 19th century, the three East Asian countries sought to transform themselves into modern nation-states. Modern nation-states maximize their internal resources in the form of mobilization for national prosperity and military service, and seek to maximize national interests through diplomacy and war. From the standpoint of the modern nationstate, China and Japan thought the expansion of influence in Korea, rather than the dismantling of the East Asian unequal treaty system through mutual cooperation, would promote their own national interests. Therefore, China and Japan pointed out the unequal nature of the Korean treaties, while at the same time carried out contradictory policies to conclude their own unequal treaties with Korea.

\section{References}

1. Auslin, Michael R. Negotiating with Imperialism: The Unequal Treaties and the Culture of Japanese Diplomacy. Cambridge: Harvard University Press, 2009.

2. Duus, Peter and Ramon H. Meyers and Mark R. Peattie, eds. The Japanese Informal Empire in China, 1895-1937. Princeton: Princeton University Press, 1989.

3. Fairbank, John K. "The Creation of the Treaty System." In The Cambridge History of China, Vol.10. Late Ch'ing, 1800-1911. Part 1. 
New York: Cambridge University Press, 1978.

4. Han, Cheol-ho. "Kabogaehyŏk·Agwanp'ach'ŏn'gi (1894 1897) Ilbonŭi Ch'ioebŏpkwŏn Haengsawa Chosŏnŭi Taeŭng (Japan's Exercise of 'Extraterritoriality' and Korea's Response, 1894 1897)." Han'gungminjogundongsayŏn'gu 56 (September 2008): 5 49.

5. Han, Seunghoon. "Choyŏngjoyak (1883. 11) kwa Pulp'yŏngdŭngjoyakch'ejeŭi Chaejŏngnip (The Treaty Concluded between Korea and Britain in 1883 and the Reconstruction of the Unequal Treaty System)." Han'guksayŏn'gu 135 (December 2006): 215-50.

6. Han, Seunghoon. "19Segi Huban Chosŏnŭi Taeyŏngjŏngch'aek Yŏn'gu (1874 1895): Chosŏnŭi Kyunsejŏngch'aekkwa Yŏnggugŭi Kansŏpchŏngch'aegŭi Kwan'gye Chŏngnipkwa Kyunyŏl (Korean Policy toward Britain in the late 19th century: The Establishment and Rupture between Korean Policy of Balance of Power and British Policy of Intervention).” PhD diss., Korea University, 2015.

7. Inō, Tentaro (稲生田太郎). Higashiajia Ni Okeru Fubyōdo- Joȳaku Taisei To Kindai Nihon (Modern Japan and the Unequal Treaty System in East Asia). Tokyo: Iwata Shoin, 1995.

8. Iokibe, Kaoru (五百旗頭薰). Joyaku Kaiseishi: Hoken Kaifuku eno Tenbo to Nashonarizumu (Meiji Treaty Revision: Prospect for a Unified jurisdiction and Nationalism). Tokyo: Yūhikaku, 2010.

9. Jones, Francis C. "Foreign Diplomacy in Korea 1866 1894." PhD diss., Harvard University, 1935.

10. Kim, Hyun-soo. "P'ak'ǔsŭ (Sir Harry Parkes) Kwallyŏn Saryodŭrŭl T'onghae Pon 'Hanyŏngsuhot'ongsangjoyak' Ch'egyŏl Kwajŏng (A Study of the Anglo-Korean Treaty by Reviewing Sir H. Parkes' Documents)." Yŏnggugyŏn'gu 11 (June 2004): 63-88.

11. Kim, Hyun-soo. Taeyŏngjegugŭi Tongasia Oegyojuyŏk: Haeri S. $P^{\prime} a k^{\prime} u \breve{s u ̆ ~(H a r r y ~ S . ~ P a r k e s: ~ L e a d e r ~ o f ~ G r e a t ~ B r i t a i n ' s ~ d i p l o m a c y ~ i n ~}$ East Asia). Yongin: Dankook University Press, 2011.

14. Kim, Key-Hiuk. The Last Phase of the East Asian World Order: Korea, Japan, and the Chinese Empire, 1860-1882. Berkeley: University of California Press, 1980. 
15. Kim, Key-Hiuk. "Kaehangŭl Tullŏssan Kukchejŏngch'i (International Politics surrounding the Opening of Portsin Korea)." Han'guksa Simin'gangjwa 7 (August 1990).

16. Kim, Kyung-Tae. "Kaehangjikhuŭi Kwansegwŏn Hoebongmunje: Pusanhaegwan Susesagŏnŭl Chungsimŭro (The Restoration of Tariff-rights in the Late 19th Century: The Case of 'Pusan Tariff Incident').” Han'guksayŏn'gu 8 (September 1972): 693-723.

17. Kim, Kyung-Tae. "Pulp'yŏngdŭngjoyak Kaejŏnggyosŏbŭi Chŏn'gae: 1880nyŏn Chŏnhuŭi Taeil 'Minjongmunje' (Negotiations for the Amendment of the unequal treaty: 'National problem' against Japan around 1880)." Han'guksayŏn'gu 11 (September 1975): 165-204.

18. Lee, Byeong Cheon. "Kaehanggwa Pulp'yŏngdŭngjoyakch'ejeŭi Hwangnip (A Study on the Establishment of the Unequal Treaty System during the Port: Opening Period)." Kyŏngjesahak 8 (December 1990): 61-107.

19. Song, Byeong-Ki. "Kimyunsik, Leehongjangŭi Pojŏng Ch'ŏnjinhoedam (Sang): Chomijoyak Ch'egyŏl (1882) ŭl Wihan Choch'ŏnggyosŏp (Kim Yun-Sik - Li Hung-chang Talks at Poating and Tientsin: The Korean-Chinese Negotiations for the Conclusion of Korean-American Treaty in 1882)." Tongbanghakchi 44 (November 1984): 157-99.

20. Park, Han-min. "1878nyŏn Tumojin Suserŭl Tullŏssan Choil Yanggugŭi Insikkwa Taeŭng (The recognition and response of the Korea and Japan surrounding the Tumojin Incident in 1878)." Hanilgwan'gyesayŏn'gu 39 (August 2011): 369-421.

21. Wang, Dong. China's Unequal Treaties: Narrating National History. Lanham: Lexington Books, 2008.

22. Wang, Shaofang (王紹坊). Zhongguo Wai Jiao Shi: Yapian Zhan Zhen Zhi Xin Hai Ge Ming Shi Qi, 1840-1911 (Diplomatic story of China from the Opium War to the 1911 Revolution). Kaifeng: Henan ren min chu ban she, 1988.

23. Yamamoto, Shigeru (山本茂). Jōyaku Kaiseishi (History of Treaty 
Amendment). Tokyo: Kousan Shouin, 1943. 


\section{The Endeavour to Revise Unequal Treaties in East Asia in the Early 1880s}

This article aims to identify possible changes in the East Asian unequal treaty system in the early 1880 s. In 1880 , Korea confirmed that China and Japan had suffered from economic damage due to the loss of 5 percent import duty rate and tariff autonomy, and that Japan was preparing the Western powers to revise treaties. Therefore, Korea drafted a treaty that guaranteed the tariff rate of $10 \%$ on major imports and Korea's tariff autonomy based on Japan's draft of a treaties revision toward Western powers. China, which mediated the settlement of the treaties between Korea and Western powers, secured Korea with an import tariff rate of 10-30\% and tariff autonomy. However, China applied a 5 percent import tariff to Korea, which was in effect in China and Japan, through Regulations for Maritime and Overland Trade between Chinese and Korean Subjects (1882). Japan also applied an import tariff of 8 percent and denied Korea's tariff autonomy in regulations under which Japanese trade is to be conducted in Korea (1883). In the extension, Korea and Britain set a tariff rate of $7.5 \%$ on major imports in the second Korea-Britain Treaty (1883). The 7.5\% tariff was higher than the 5\% tariff in China and Japan. However, the $7.5 \%$ tariff was the amount of the import duties and transit duties of China combined. Although Japan imposed only a 5\% tariff, she strictly prohibited Westerners' trade in areas other than the open ports. On the other hand, according to the second Korea-Britain Treaty, Korea imposed a tariff of $5 \%$ and $7.5 \%$ on most imports. The average tariff applied in Korea was only about 7\%. Furthermore, Westerners in Korea were free to trade in all areas as well as open ports. The possibility of revising the East Asian unequal treaty system, which was proposed since 1880 , ended up being disadvantageous to Korea. 
Keywords: unequal treaty system in East Asia, import tariff, tariff autonomy, Regulations for Maritime and Overland Trade between Chinese and Korean Subjects (1882), Regulations under which Japanese trade is to be conducted in Korea (1883), the second Korea-Britain Treaty (1883). 


\section{〈국문초록〉}

\section{0 년대 초반 동아시아 국가들의 불평등조약 개정 시도}

한승훈 (고려대 독일어권문화연구소 연구교수)

이 글은 1880 년대 초반 동아시아 불평등조약체제의 변화 가능성을 밝히는데 목적이 있다. 1880 년에 조선은 청국과 일본이 $5 \%$ 의 수입관세율과 관세자주권의 상실로 경제 적 손실을 입게 된 사실과 일본이 서구 열강에 조약 개정을 준비한다는 점도 확인하였 다. 이에 조선은 일본 측 초안을 근거로 수입품에 대한 관세율을 $10 \%$ 로 정하고, 조선 의 관세자주권을 보장하는 조약 초안을 작성하였다. 청국은 조선과 서구 열강의 조약 체결을 중재하면서 조약 내에 조선이 $10 \sim 30 \%$ 의 수입관세율과 관세자주권을 보장받도 록 하였다. 그런데 청국은 조청상민수륙무역장정(1882)을 통해서 청국과 일본에서 시 행중이었던 5\%의 수입관세율을 조선에 적용시켰다. 일본 역시 조일통상장정(1883)에 서 $8 \%$ 의 수입관세율을 조선에 적용시켰을 뿐만 아니라 조선의 관세자주권을 부정하였 다. 그 연장선에서 조선과 영국은 제 2 차 조영조약(1883)에서 주요 수입품에 대한 관세 율을 $7.5 \%$ 로 정하였다. 제 2 차 조영조약의 $7.5 \%$ 관세율은 청국과 일본에서 시행중인 $5 \%$ 보다는 높았다. 하지만 $7.5 \%$ 는 $5 \%$ 의 관세율에 $2.5 \%$ 의 내지통행세가 별도로 부과 되었던 청국의 실질관세율과 동일하였다. 비록 일본은 $5 \%$ 의 관세율만 부과하였지만, 개항장 이외 지역에서 서양인들의 상행위를 엄격히 금지하였다. 반면에 제 2 차 조영조 약에서는 대다수 수입품에 대해서 $5 \%$ 와 $7.5 \%$ 의 관세율을 부과하였다. 즉 실질적으로 조선에 적용되었던 평균 관세율은 $7 \%$ 정도에 불과하였다. 더군다나 조선에서 서양인 들은 개항장 이외의 모든 지역에서 자유로운 상행위가 가능하였다. 결과적으로 1880 년 부터 제기되었던 동아시아 불평등조약체제의 개정 가능성은 조선에 불리하게 귀결되었 던 것이다.

주제어: 동아시아 불평등조약체제, 수입관세율, 관세자주권, 조청상민수륙무역 장정, 조일통상장정, 제 2 차 조영조약 
